\title{
22. METHANOGENIC ACTIVITY IN SEDIMENT FROM LEG 64, GULF OF CALIFORNIA ${ }^{1}$
}

\author{
Ronald S. Oremland and Charles Culbertson, U.S. Geological Survey, Menlo Park, California \\ and \\ Bernd R. T. Simoneit, ${ }^{2}$ Institute of Geophysics and Planetary Physics, \\ University of California-Los Angeles, Los Angeles, California
}

\begin{abstract}
We detected methanogenic bacterial activity in 6 of 12 sediment samples from Deep Sea Drilling Project (DSDP) locations in the Gulf of California. When samples were incubated anaerobically for three weeks at temperatures of 10 or $22^{\circ} \mathrm{C}$, we found activity to sediment depths of about 12 meters. The methanogenic bacteria were inhibited by $\mathrm{CHCl}_{3}$ or 2-bromoethanesulfonic acid and were generally stimulated by $\mathrm{H}_{2}$.
\end{abstract}

\section{INTRODUCTION}

Methanogenic bacteria inhabit a diverse array of anaerobic environments, including hot springs (Ward, 1978), trees (Zeikus and Ward, 1974), and the intestinal tracts of terrestrial and aquatic animals (Hungate, 1966; Oremland, 1979). Recently, there has been increased interest in bacterial methanogenesis in freshwater (Cappenberg, 1974; Belyaev and Finkel'shtein, 1975; Winfrey and Zeikus, 1977) and marine sediment (Martens and Berner, 1974; Oremland, 1975; Oremland and Taylor, 1978). These studies limited their investigations to shallow waters accessible either to SCUBA divers or simple coring devices. Geochemical investigations of sediment from the deeper continental shelf, slope, or abyssal plain (Emery and Hoggan, 1958; Claypool and Kaplan, 1974; Bernard et al., 1978) delineated the abundance of bacterially derived methane in a variety of sedimentary environments but have not determined whether biological methanogenesis is ongoing. Biological experiments with deep oceanic sediments have been confined to the upper few meters of the sedimentary column, because samples were recovered by gravity corers. Kosiur and Warford (1979) found methanogenic activity in sediment from the upper 3.3 meters of the Santa Barbara Basin, and Belyaev and Laurinavichus (1977) reported activity in the surface sediment in the Gulf of California (Fig. 1). Romesser et al. (1979) isolated two new species of marine methanogenic bacteria from surface sediment in the Cariaco Trench and the Black Sea. The Deep Sea Drilling Project investigated the presence of methanogens at greater sedimentary depths; this chapter describes our initial findings.

\section{METHODS AND MATERIALS}

For biological incubations, we used portions of 12 samples, originally collected for geochemical studies. The samples came from the upper 30 meters of sediment from 6 Gulf of California drilling sites (Fig. 1). Sediment samples (about $150-250 \mathrm{~cm}^{3}$ ) were sealed in labeled plastic bags (Kapak) and refrigerated $\left(6^{\circ} \mathrm{C}\right)$. After three

\footnotetext{
${ }^{1}$ Curray, J. R., Moore, D. G., et al., Init. Repts. DSDP, 64: Washington (U.S. Govt. Printing Office).

2 Present address: School of Oceanography, Oregon State University, Corvallis, Oregon.
}

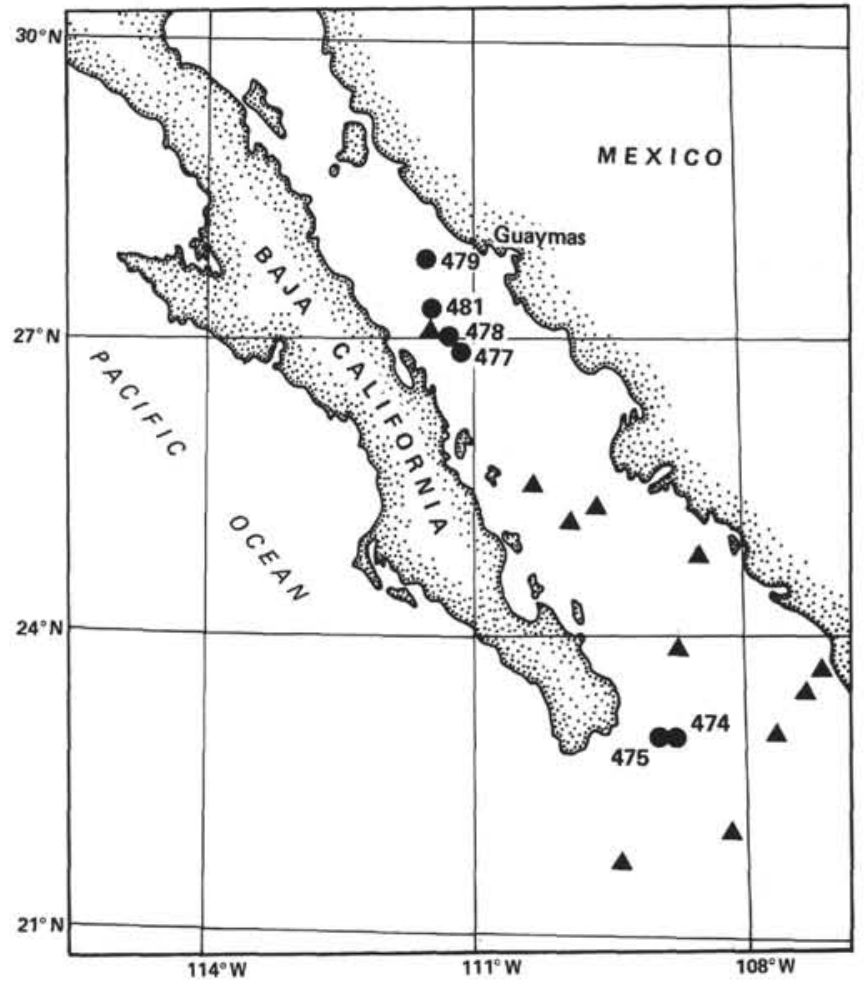

Figure 1. Deep Sea Drilling Project/IPOD drilling sites $(\bullet)$ in the Gulf of California shown in relation to sites analyzed by Belyaev and Laurinavichus ( $\mathbf{\Delta})$.

months' storage, we transferred the sediment to jars sealed under $\mathrm{N}_{2}$ and refrigerated the samples at $6^{\circ} \mathrm{C}$. At two of the coring sites (Holes 475 and 477), we collected samples from four depths down to 26.5 and 21.4 meters, respectively. At each of four sites (Holes 474, 478, 479, and 481 ), we collected only one sample (Table 1 ).

A $3-\mathrm{cm}^{3}$ portion of sediment from each core was subsampled and dispensed into test tubes by the use of plastic syringes (alcohol-sterilized) with the ends cut off (to facilitate subcoring). The test tubes (18 $\times 150 \mathrm{~mm}$ ) contained $5 \mathrm{ml}$ of the following media: one liter of Pacific coastal seawater, $\mathrm{K}_{2} \mathrm{HPO}_{4}(0.25 \mathrm{~g}), \mathrm{KH}_{2} \mathrm{PO}_{4}(0.25 \mathrm{~g}), \mathrm{NH}_{4} \mathrm{Cl}(1.0 \mathrm{~g})$, Wolin et al. (1963) trace-element solution (10 ml), Wolin et al. (1963) vitamin solution $(10 \mathrm{ml})$, cysteine- $\mathrm{HCl}(0.0625 \mathrm{~g}), \mathrm{Na}_{2} \mathrm{~S} \cdot 9 \mathrm{H}_{2} \mathrm{O}(0.0625$ $\mathrm{g})$, and resazurin $(0.002 \mathrm{~g})$. We stirred the seawater $(\mathrm{S}=32 \%$ ) with activated charcoal for $20 \mathrm{~min}$. (to remove organic matter) then filtered and autoclaved $(15 \mathrm{psi} / 15 \mathrm{~min}$.) the mixture. We added the remaining ingredients by filter sterilization (Millex, $0.22 \mu \mathrm{m}$ ). The medium was 
Table 1. Changes in methane concentrations in DSDP sediment tubes.

\begin{tabular}{|c|c|c|c|c|c|}
\hline \multirow{2}{*}{$\begin{array}{c}\text { Sample } \\
\text { (interval in } \mathrm{cm} \text { ) }\end{array}$} & \multirow{2}{*}{\multicolumn{2}{|c|}{ Sub-bottom Depth (m) }} & \multicolumn{3}{|c|}{ Methane $(n \mathrm{~mol} . / \mathrm{ml})$} \\
\hline & & & $\mathrm{N}_{2}$ & $\mathrm{H}_{2}$ & $\mathrm{CHCl}_{3}$ \\
\hline \multicolumn{6}{|c|}{ A } \\
\hline $474-2, \mathrm{CC}$ & 7.20 & (11.5) & 0.10 & 0.29 & 0.13 \\
\hline $475 \mathrm{~B}-1-2,145-150$ & 2.98 & & 0.11 & 0.20 & 1.13 \\
\hline $475-2-1,145-150$ & 7.48 & & 0.10 & 12.4 & 0.13 \\
\hline $475-3-1,145-150$ & 16.98 & & 0.04 & 0.09 & 0.08 \\
\hline $475-4-1,145-150$ & 26.48 & & 0.04 & 0.11 & 0.12 \\
\hline $477-2-2,140-145$ & 3.93 & (8.7) & 3.08 & 8.96 & 0.16 \\
\hline 477B-1,CC & 3.50 & (4.6) & 8.79 & 14.88 & 0.21 \\
\hline $477-3-1,130-135$ & 11.82 & $(18.2)$ & 8.62 & 8.81 & 1.53 \\
\hline $477-4-1,140-145$ & 21.43 & $(29.2)$ & 0.45 & 0.51 & 0.44 \\
\hline $478-2-5,115-120$ & 10.68 & & 7.01 & 6.15 & 0.47 \\
\hline $479-1-1,134-140$ & 1.37 & (1.9) & 0.10 & 0.20 & 0.13 \\
\hline $481-1-2,140-145$ & 2.93 & $(4.5)$ & 18.04 & 8.59 & 0.05 \\
\hline \multicolumn{6}{|c|}{ B } \\
\hline $474-2, \mathrm{CC}$ & 7.20 & (11.5) & 0.37 & 0.46 & 0.38 \\
\hline $475 \mathrm{~B}-1-2,145-150$ & 2.98 & & 0.04 & 0.09 & 0.03 \\
\hline $475-2-1,145-150$ & 7.48 & & 0.46 & 0.05 & 0.08 \\
\hline $475-3-1,145-150$ & 16.98 & & 0.05 & 0.04 & 0.05 \\
\hline $475-4-1,145-150$ & 26.48 & & 0.01 & 0.03 & 0.07 \\
\hline $477-2-2,140-145$ & 3.93 & $(8.7)$ & 4.94 & 12.74 & 0.07 \\
\hline 477B-1,CC & 3.50 & (4.6) & 3.03 & 3.65 & 0.09 \\
\hline $477-3-1,130-135$ & 11.82 & (18.2) & 4.01 & 1.28 & 0.66 \\
\hline $477-4-1,140-145$ & 21.43 & $(29.2)$ & 0.25 & 0.20 & 0.19 \\
\hline $478-2-5,115-120$ & 10.68 & & 0.07 & 4.36 & 0.07 \\
\hline $479-1-1,134-140$ & 1.37 & (1.9) & 0.05 & 0.08 & 0.09 \\
\hline $481-1-2,140-145$ & 2.93 & (4.5) & 4.53 & 3.55 & 0.06 \\
\hline
\end{tabular}

Note: Depths are calculated by the DSDP convention of measuring down from the top of each core. But in these soft sediments, it is felt that the core catcher (CC) contains material drilled last, and therefore the depths calculated upwards from the core catcher are given (if different) in parentheses. The difference represents an absolute depth uncertainty. A. Incubated at $22^{\circ} \mathrm{C}$ for 20 days. B. Incubated at $10^{\circ} \mathrm{C}$ for 20 days. $\mathrm{CHCl}_{3}$ controls were incubated under $\mathrm{N}_{2}$.

gassed while still warm with a flow of $\mathrm{O}_{2}$-free $\mathrm{N}_{2}$, and we adjusted the final $\mathrm{pH}$ to 6.9. After reducing the medium (resazurin colorless), we dispensed it into sterile test tubes (each sealed with a No. 1 recessed butyl rubber stopper) (Hungate, 1979). The tubes were incubated in the upright position without shaking, and, for inhibited control, we added $\mathrm{CHCl}_{3}(0.05 \mathrm{ml})$ or BES (2-bromethanesulfonic acid; $10^{-3} \mathrm{M}$ ) to selected tubes (Bauchop, 1967; Gunsalus et al., 1978).

We agitated all tubes for several seconds after inoculation to disperse the sediment. Tubes were agitated prior to each gas chromatographic (GC) analysis to facilitate exchange of $\mathrm{CH}_{4}$ to the gas phase $($ vol. gas phase $=18 \mathrm{ml})$. We determined methane by flame ionization detection (FID) gas chromatography, using a HewlettPackard 5730 gas chromatograph equipped with a Porapak Q column $(183 \times 0.16 \mathrm{~cm}$ OD) and helium carrier gas $(30 \mathrm{ml} / \mathrm{min}$. $)$. Using a gas syringe, we withdrew the samples (Oremland and Taylor, 1978). We performed two experiments. First, we examined the samples for methanogenic activity. The samples were incubated under $\mathrm{H}_{2}$ or $\mathrm{N}_{2}$ atmospheres with appropriate $\mathrm{CHCl}_{3}$ controls. We held one set of samples at room temperature $\left(22^{\circ} \mathrm{C}\right)$ and an identical set at $10^{\circ} \mathrm{C}$ for three weeks. Second, we compared sediment from a core sample (from Hole 477B), which had demonstrated activity in the first experiment, to anaerobic sediment obtained from the Orca Basin and San Francisco Bay. The hypersaline Orca Basin sediment was recovered from the Gulf of Mexico by gravity corer in April 1978 and stored in a sealed jar under $\mathrm{N}_{2}\left(6^{\circ} \mathrm{C}\right)$. We used only the "reduced" black mud underlying about $2 \mathrm{~cm}$ of a brown oxidized layer. San Francisco Bay sediment (upper $150 \mathrm{~cm}$ ) was collected from an anoxic intertidal area studied previously (Oremland and Silverman, 1979). We incubated the sediment at room temperature in triplicate under $4: 1$ mixtures of $\mathrm{H}_{2}: \mathrm{CO}_{2}$ or $\mathrm{N}_{2}: \mathrm{CO}_{2}$ with BES controls. We included carbon dioxide in the gas phase of Experiment 2, since it is metabolized by all methanogenic bacteria (Wolfe, 1971) and may have limited bacterial activity in Experiment 1. As reported elsewhere in this volume, the organic geochemical data for the DSDP sediment were determined on board ship.

\section{RESULTS}

Experiment 1. Significant bacterial production of methane occurred in 5 of the 12 DSDP samples incubated at $22^{\circ} \mathrm{C}$ and in 6 of the 12 samples incubated at $10^{\circ} \mathrm{C}$. Chloroform-inhibited controls demonstrated increases in methane, but, with the exceptions of Sections 475B-1-2 and 477-3-1 (both at $20^{\circ} \mathrm{C}$ ), these increases were minor (Table 1). The results from a few tubes were borderline cases (e.g., Sample $474-2, \mathrm{CC}$ at $22^{\circ} \mathrm{C}$ ) in which methane levels were slightly higher in the experimental tubes than in the $\mathrm{CHCl}_{3}$ controls. Because we ran no replicate samples, it was difficult to assess whether these samples represent error or real bacterial production.

Activity commenced within a few days of incubation, and $\mathrm{H}_{2}$ usually stimulated methanogenesis (Fig. 2). Activity in Hole 477 occurs at 3.50, 3.93, and 11.82 meters but not at 21.43 meters. Hole 475 had obvious activity only at 7.48 meters (Table 1 ). We also found activity in Holes 478 and 481 but not in Holes 474 or 479 .

An apparent correlation exists (Table 2) between the number of methane-positive incubation tubes (maximum of 4) and various sediment parameters determined on shipboard (cf., Simoneit, "Organic Geochemistry," this volume). Methane was a component of the interstitial gases in all the cores showing positive incuba-

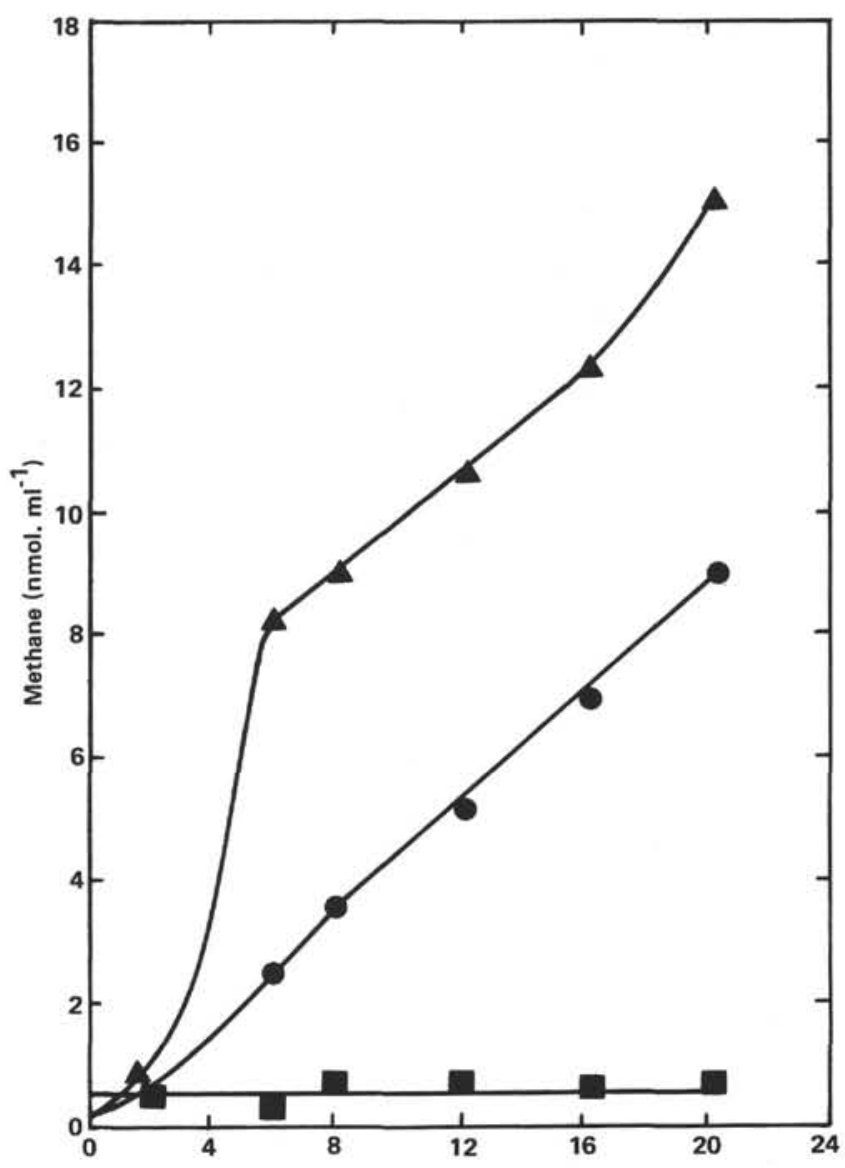

Figure 2. Experiment 1: Stimulation of methanogenesis by $\mathrm{H}_{2}$ in sediment from Sample 477B-1, CC incubated at room temperature ( $\Delta$ $=\mathrm{H}_{2} ; \bullet=\mathrm{N}_{2} ; \mathbf{\square}=\mathrm{CHCl}_{3}\left(\mathrm{~N}_{2}\right)$. 
Table 2. Results of Experiment 1 (methanogenic activity) listed with other sediment parameters.

\begin{tabular}{|c|c|c|c|c|c|c|}
\hline $\begin{array}{c}\text { Sample } \\
\text { (interval in } \mathrm{cm} \text { ) }\end{array}$ & Sub-bottom Depth (m) & Positives $^{a}$ & $\mathrm{CH}_{4}{ }^{\mathrm{b}}$ & $\mathrm{H}_{2} \mathrm{~S}^{\mathrm{C}}$ & $\mathrm{C} / \mathrm{N}$ & $\mathrm{H}_{2} \mathrm{O}\left(\%_{0}\right)$ \\
\hline $477-2-2,140-145$ & $3.93(8.7)$ & 4 & + & - & 11 & 65 \\
\hline $477 \mathrm{~B}-1 . \mathrm{CC}$ & $3.50(4.6)$ & 4 & + & - & 11 & 65 \\
\hline $477-3-1,130-135$ & $11.82(18.2)$ & 4 & + & - & 12 & 63 \\
\hline $481-1-2,140-145$ & $2.93(4.5)$ & 4 & + & + & 11 & $60-85$ \\
\hline $478-2-5,115-120$ & 10.68 & 3 & + & + & 11 & 69 \\
\hline $475-2-1,145-150$ & 7.48 & 2 & - & - & 12 & 58 \\
\hline $474-2, \mathrm{CC}$ & $7.20(11.5)$ & 1 & + & + & $\mathrm{ND}^{\mathrm{d}}$ & 45 \\
\hline $477-4-1,140-145$ & $21.43(29.2)$ & 0 & + & + & 12 & 60 \\
\hline $475 B-1-2,145-150$ & 2.98 & 0 & - & - & 14 & 60 \\
\hline $475-3-1,145-150$ & 16.98 & 0 & - & + & 12.4 & 55 \\
\hline $475-4-1,145-150$ & 26.48 & 0 & - & + & 13 & 53 \\
\hline $479-1-1,134-140$ & $1.37(1.9)$ & 0 & + & + & 11 & 78 \\
\hline \multicolumn{7}{|c|}{$\begin{array}{l}\text { a Total methane positive tubes. Maximum number is } 4\left(\mathrm{~N}_{2} \text { or } \mathrm{H}_{2} \text { at } 10^{\circ} \mathrm{C} \text { or } 22{ }^{\circ} \mathrm{C}\right) \text {. } \\
\text { b Methane in interstitial gas of the core sample. Sections } 474-2, \mathrm{CC}(11.5 \mathrm{~m}), 477-4-1(21.43 \mathrm{~m}) \\
\text { and } 479-1-1(1.4 \mathrm{~m}) \text { had } 76,80 \text {, and } 90 \% \text { methane, respectively. All other positives were trace } \\
\text { quantities. } \\
\text { c } \mathrm{H}_{2} \mathrm{~S} \text { was detected by odor, except for Section } 474-1 . \mathrm{CC}(11.5 \mathrm{~m}) \text { and Core } 479.1-1(1.4 \mathrm{~m}) \\
\text { where the detection was made by GC. } \\
\text { d Not determined. }\end{array}$} \\
\hline
\end{tabular}

tion results. (Sample 475-2-1, 145-150 cm was the only exception.) There may be a pattern of lower $\mathrm{C} / \mathrm{N}$ ratios and higher water content associated with methanogenic activity, but this observation is based on too few samples to draw any definite conclusions. The organic carbon ranges between 1.7 and $3.6 \%$; but there was no obvious correlation with methanogenesis. Sample 479-1-1, $134-140 \mathrm{~cm}$ was an exception. It lacked methanogenic activity but had a low $\mathrm{C} / \mathrm{N}$ ratio, a high water content, and interstitial methane. Hydrogen sulfide was presumably biogenic but showed no pattern in relation to methanogenic activity.

Experiment 2. Methanogenic activity in the Gulf of California samples incubated under $\mathrm{N}_{2}: \mathrm{CO}_{2}$ at first lagged behind San Francisco Bay sediment, but production rates were similar after eight days of incubation (Fig. 3). Orca Basin sediment demonstrated no activity under

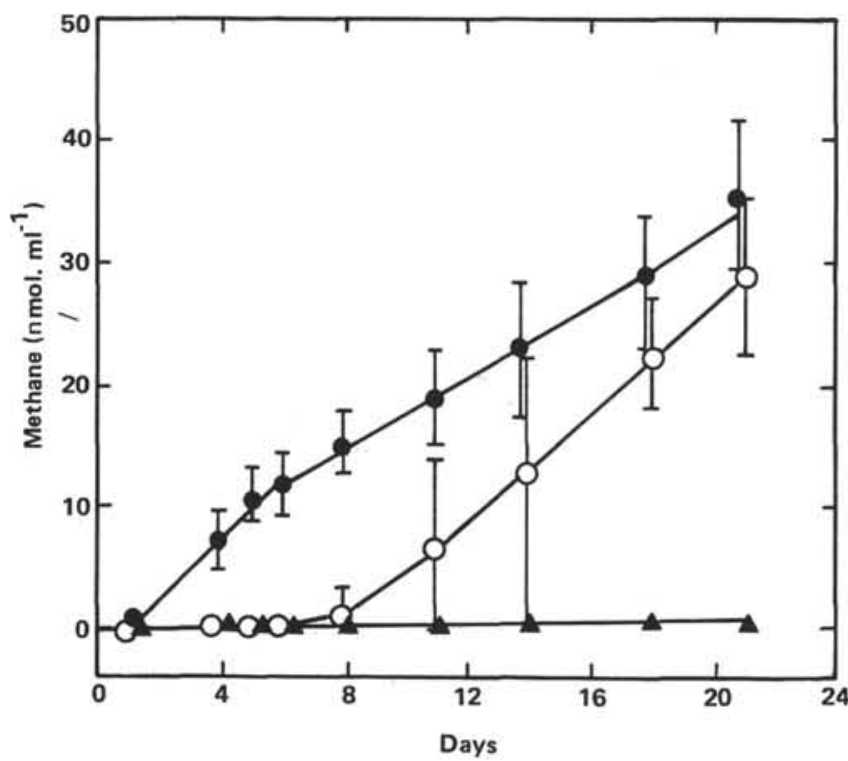

Figure 3. Experiment 2: Section 477B-1,CC (O), San Francisco Bay sediment $(\bullet)$, Orca Basin sediment $(\boldsymbol{\Delta})$ incubated under $\mathrm{N}_{2}: \mathrm{CO}_{2}$. (Points indicate the mean, \pm 1 Std. Dev. (bars) of triplicate tubes. Error for Orca brine samples was too small to plot.)
$\mathrm{N}_{2}: \mathrm{CO}_{2}$ (Fig. 3) or $\mathrm{H}_{2}: \mathrm{CO}_{2}$ (not shown). Some stimulation of the Gulf of California samples occurred under $\mathrm{H}_{2}$, although there was a large error associated with the samples (Table 3). By contrast, San Francisco Bay sediment was stimulated 40 -fold when $\mathrm{H}_{2}$ was substituted for $\mathrm{N}_{2}$ (data not shown).

\section{DISCUSSION}

The results are a brief reconnaissance of the ability of upper sediments of the Gulf of California to evolve methane biologically. We have demonstrated that methanogenic bacteria are present down to 11.82 meters, but their distribution is "patchy." We found activity in only one (Sample 475-2-1, 145-150 cm) of the five sediment samples from the two holes at the mouth of the Gulf. But the cores from the Guaymas Basin had a more extensive distribution of methanogens ( 3 of the 4 cores and 5 of the 7 sediment samples). Only the deepest portion of the cores from Holes $477(21.3 \mathrm{~m}$ ) and 479 (on the northern end of the Basin) lacked activity. Belyaev and Laurinavichus (1977) found methanogenic activity in all the surface samples (upper $170 \mathrm{~cm}$ ) of their Gulf of California stations (Fig. 1). The lack of activity in some of our samples does not eliminate the possibility of methanogens in those sampling holes or at greater depths. Methanogenic bacteria are extremely sensitive to oxygen (Wolfe, 1971) and, because of operational difficulties, our samples were stored for three months without precautions to insure anaerobiosis. What is surprising, therefore, is that we detected activity in even half of the samples after such harsh treatment. In the future, work of this nature should be initiated on board ship, and freshly recovered materials should be used.

Hydrogen only slightly stimulated the DSDP sediments (Table 3 ). This result contrasts with the stimulation of methanogenesis by $\mathrm{H}_{2}$ in San Francisco Bay sediment and tropical estuarine sediment (Oremland, 1975; Oremland and Taylor, 1978). One explanation is that the DSDP organisms are evolving methane primarily from the methyl group of acetate (Cappenberg and Prins, 1974). Another is that the organisms are barophiles and require hydrostatic pressure to effectively metabolize $\mathrm{H}_{2}$. It is significant that Yayanos et al. (1979) recently isolated from the ocean floor a barophilic spirillum that demonstrated optimal growth characteristics at 500 bars. Experimental work will be conducted along these lines to discover the rate limitations on methanogenesis in DSDP samples.

Table 3. Stimulation of methanogenesis by $\mathrm{H}_{2}$ in Sample 477B$1, \mathrm{CC}$.

\begin{tabular}{rccccc}
\hline \multicolumn{5}{c}{$\begin{array}{c}\text { Methane Yield }(n \mathrm{Mol} . / \mathrm{ml}) \\
\text { Days Incubation }\end{array}$} \\
Atmosphere & 0 & 6 & 8 & 11 & 21 \\
\hline $\mathrm{H}_{2}: \mathrm{CO}_{2}$ & $0.02 \pm 0.01$ & $1.3 \pm 0.45$ & $6.8 \pm 2.1$ & $18 \pm 5.7$ & $39 \pm 8.2$ \\
$\mathrm{~N}_{2}: \mathrm{CO}_{2}$ & $0.02 \pm 0.004$ & $0.29 \pm 0.25$ & $1.3 \pm 1.5$ & $7.0 \pm 6.9$ & $29 \pm 6.3$ \\
$\mathrm{BES}+\mathrm{H}_{2}: \mathrm{CO}_{2}$ & 0.02 & 0.03 & 0.04 & 0.08 & 0.10 \\
$\mathrm{BES}+\mathrm{N}_{2}: \mathrm{CO}_{2}$ & 0.01 & 0.04 & 0.04 & 0.06 & 0.11 \\
\hline
\end{tabular}

Note: Results represent the mean \pm 1 standard deviation of three experimental tubes. BES-inhibited controls were run singly. Tubes were incubated at $22^{\circ} \mathrm{C}$. 
The Orca Basin sediments are a control for this work. Sediment from the Orca Basin demonstrated no noticeable activity in $\mathrm{H}_{2}: \mathrm{CO}_{2}$ or $\mathrm{N}_{2}: \mathrm{CO}_{2}$ atmospheres. This agrees with observations of freshly recovered materials from the Orca Basin incubated on board ship and for several subsequent months in the laboratory (Oremland, unpublished). The small amounts of methane in the DSDP $\mathrm{CHCl}_{3}$ and BES control tubes may be caused by any one of the following: (1) contamination (although this is unlikely, since separate sampling syringes were used on each sample); (2) physical desorption of methane from the sediment; (3) incomplete blockage of methanogenesis by the inhibitors; or (4) biological formation of methane from bacteria (other than methanogens) attacking methionine as a substrate (Zinder and Brock, 1978).

Methanogenic bacteria appear to have a deeper distribution in marine sediment than originally thought. In this chapter we have shown that methanogens are present to at least 12 meters in sediment of the Gulf of California. Belyaev et al. (1980) recently reported low biological production rates at depths of 90 meters in Caspian Sea sediment. Hathaway et al. (1979) observed sulfate and methane profiles in U.S. Atlantic shelf sediments to depths of 300 meters. Their results are reminiscent of nearshore sediments (Martens and Berner, 1974), the only difference being that the depletion of sulfate and the appearance of methane occur over hundreds of meters instead of centimeters. Hathaway et al. (1979) further suggested that bacteria may have been active at depth in these regions for the past $20 \mathrm{~m} . \mathrm{y}$.

\section{ACKNOWLEDGMENTS}

We are grateful to K. A. Kvenvolden and S. N. Luoma for helpful discussions in preparing this chapter. Although we mention certain brand-name products, this does not constitute an endorsement by the U.S. Geological Survey.

\section{REFERENCES}

Barnes, R. O., and Goldberg, E. D., 1976. Methane production and consumption in anoxic marine sediments. Geology, 4:297-300.

Bauchop, T., 1967. Inhibition of rumen methanogenesis by methane analogues. J. Bacteriol., 94:171-175.

Belyaev, S. S., and Finkel'shtein, L. I., 1975. Intensity of bacterial methane formation in ooze deposits of certain lakes. Microbiology, 44:272-275.

Belyaev, S. S., and Laurinavichus, K. S., 1977. Microbiological formation of methane in marine sediments. In Krumbein, W. E. (Ed.), Proc. 3rd Int. Symp. Environ. Biogeochem., pp. 327-337.

Belyaev, S. S., Lein, A. Y., and Ivanov, M. V., 1980. Role of methane-producing and sulfate-reducing bacteria in the process of organic matter destruction. In Trudinger, P. A., and Walter, M. R. (Eds.) Biogeochemistry of Ancient and Modern Environments. Proc. 4th Int. Symp. Environ. Biogeochem, pp. 235-242.

Bernard, B. B., Brooks, J. M., and Sackett, W. M., 1978. Light hydrocarbons in recent Texas continental shelf and slope sediments. J. Geophys. Res., 83:4053-4061.
Cappenberg, Th. E., 1974. Interrelationships between sulfate-reducing and methane-producing bacteria in bottom deposits of a freshwater lake. I. Field observations. Antonie van Leeuwenhoek, 40: 285-295.

Cappenberg, Th. E., and Prins, R. A., 1974. Interrelationships between sulfate-reducing and methane-producing bacteria in bottom deposits of a freshwater lake. III. Experiments with ${ }^{14} \mathrm{C}$-labeled substrates. Antonie van Leeuwenhoek, 40:457-469.

Claypool, G. E., and Kaplan, I. R., 1974. The origin and distribution of natural gases in marine sediments. In Kaplan, I. R. (Ed.), Natural Gases in Marine Sediments: New York (Plenum), pp. 99-140.

Emery, K. O., and Hoggan, D., 1958. Gases in marine sediments. Am. Assoc. Pet. Geol. Bull., 42:2174-2188.

Gunsalus, R. P., Romesser, J. A., and Wolfe, R. S., 1978. Preparation of coenzyme $M$ analogues and their activity in the methyl coenzyme $\mathrm{M}$ reductase system of Methanobacterium thermoautotrophicum. Biochemistry, 17:2374-2377.

Hathaway, J. C., Poag, C. W., Valentine, P. C., et al., 1979. U.S. Geological Survey, core drilling on the Atlantic Shelf. Science, 206:515-527.

Hungate, R. E., 1966. The Rumen and Its Microbes: New York (Academic).

1969. A roll tube method for cultivation of strict anaerobes. In Norris, J. R., and Ribbons, D. W. (Eds.), Methods in Microbiology (Vol. 3B): New York (Academic), 117-132.

Kosiur, D. R., and Warford, A. L., 1979. Methane production and oxidation in Santa Barbara Basin sediments. Est. Coastal Mar. Sci. 8:379-385.

Martens, C. S., and Berner, R. A., 1974. Methane production in the interstitial waters of sulfate-depleted marine sediments. Science, 185:1167-1169.

Oremland, R. S., 1975. Methane production in shallow water, tropical marine sediments. Appl. Microbiol., 30:602-608.

, 1979. Methanogenic activity in plankton samples and fish intestines: A mechanism for in situ methanogenesis in oceanic surface waters. Limnol. Oceanog., 24:1136-114.

Oremland, R. S., and Silverman, M. P., 1979. Microbial sulfate reduction measured by an automated electrical impedance technique. Geomicrobiol. J., 1:355-372.

Oremland, R. S., and Taylor, B. F., 1978. Sulfate reduction and methanogenesis in marine sediments. Geochim. Cosmochim. Acta, 42: 209-214.

Romesser, J. A., Wolfe, R. S., Mayer, F., et al., 1979. Methanogenium, a new genus of marine methanogenic bacteria and characterization of Methanogenium cariaco sp. nov. and Methanogenium marinigri sp. nov. Arch. Microbiol., 121:147-153.

Ward, D. N., 1978. Thermophilic methanogenesis in a hot-springs algo-bacterial mat $\left(71-30^{\circ} \mathrm{C}\right)$ Appl. Environ. Microbiol. 35: 1019-1026.

Winfrey, M. R., and Zeikus, J. G., 1977. Effect of sulfate on carbon and electron flow during microbial methanogenesis in freshwater sediments. Appl. Environ. Microbiol., 33:275-281.

Wolfe, R. S., 1971. Microbial formation of methane. Adv. Microb. Physiol., 6:107-149.

Wolin, E. A., Wolin, M. J., and Wolfe, R. S, 1963. Formation of methane by bacterial extracts. J. Biol. Chem., 238:2882-2886.

Yayanos, A. A., Dietz, A. S., and van Boxtell, R., 1979. Isolation of a deep-sea barophilic bacterium and some of its growth characteristics. Science, 205:808-809.

Zeikus, J. G., and Ward, J. G., 1974. Methane formation in living trees: A Microbiological origin. Science, 184:1181-1183.

Zinder, S. H., and Brock, T. D., 1978. Methane, carbon dioxide and hydrogen sulfide production from the terminal methiol group of methionine by anaerobic lake sediments. Appl. Environ. Microbiol., 35:344-352. 